\title{
Legitimering gjennom (selektiv) felles fortid: russisk bruk av historie i Ukraina-konflikten
}

\author{
Minda Holm* \\ MSc, M.I.S., juniorforsker ved forskningsgruppen for utenrikspolitikk og diplomati, \\ NUPI
}

\begin{abstract}
Legitimation Through a (Selective) Shared Past: Russia's Use of History in the Conflict in Ukraine

How has Russia used history to justify its actions in the conflict in Ukraine? Through an analysis of official statements of the Ministry of Foreign Affairs, as well as speeches and remarks by Putin, this article argues that history has played an important but varying role in official rhetoric. With Crimea, the emphasis was on the 'sanctity' of the territory for Russian Orthodox identity, drawing on history dating back to the baptism of Prince Vladimir in 10th century AC. The shared past of the two states has not been as central in official Russian policy justification regarding Ukraine outside Crimea: the 'brotherhood' of the two nations has been noted repeatedly, but usually secondary to arguments pertaining to economic and political interests. The two world wars have been used as a cautionary tale, with Russia effectively seeking to delegitimize the new Ukrainian government by evoking carefully selected elements of its past. Finally, the author looks at the use of international precedence as a form of justification, turning the history of Western - US in particular actions back on Russia's critics. The official usage of history is placed within broader strategies of legitimation, as it is not enough to study propaganda and manipulation strategies as part of information warfare to explain how the Kremlin achieves support for its policies. The 'thick' historical narratives of Crimea play on elements linked to issues of national identity, making it difficult to dispute using the type of counter-propaganda and rebuttal of disinformation proposed by some.
\end{abstract}

Keywords: War in Ukraine, uses of history, Russian rhetoric, public legitimation

Konflikten som brøt ut i Ukraina høsten 2013 over en såkalt Assosiasjonsavtale med EU har medført enorme endringer for mange ukrainere. Etter at protestene brøt ut på Majdan har landet gått gjennom avsettelsen av en korrupt, men folkevalgt president, russisk anneksjon ${ }^{1}$ av Krim mars 2014 og en borgerkrig med tydelig

\footnotetext{
^Kontaktinformasjon: Minda Holm. Email: minda.holm@nupi.no

${ }^{1}$ Jeg holder meg i denne artikkelen til den folkerettslige betegnelsen «anneksjon» som beskrivelse av Krims endrede politiske status, til forskjell fra russisk «gjenforening». 
russisk tilstedeværelse. FN estimerer sommeren 2016 at mer enn 9500 har dødd siden konflikten brøt ut, og rundt 1,3 millioner er internt fordrevne (UN News Centre 2016a; 2016b).

Konflikten har hatt åpenbare konsekvenser også utenfor de ukrainske landegrensene. EU og USA har plassert Russland under sanksioner, NATO har suspendert samarbeidet med Russland, G8 Russlands medlemskap, og flere trekker paralleller til en ny «kald krig». Innenfor denne konteksten har det offentlige diskusjonsklimaet også blitt betydelig polarisert. Den russiske posisjonen i konflikten blir i amerikansk og europeisk presse fremstilt som aggressiv og i arrogant brudd med folkeretten. Fokuset i faglige analyser av den russiske rollen i konflikten har gjerne fokusert på motiv (Allison 2014; Götz 2015; Tsygankov 2015) eller fremgangsmåte, med særlig oppmerksomhet rettet mot russisk hybrid-krigføring og «informasjonskrig» (Darczewska 2014; Giles 2016; Pomerantsev 2015; Popescu 2015).

I litteraturen om informasjonskrig trekker forskere frem manipulasjon og løgn fra russisk side. Dette kommer i tillegg til andre strategier, som kontroll over tradisjonell media, infiltrering og kontroll over sosial media, sanksjoner mot utenlandsk presse og begrensinger i folks internettbruk (Giles 2016: 30-34; Dougherty 2015). Pomerantsev mener eksempelvis at Kremlins informasjonsstrategi har ført til «kyniske borgere, formet av propaganda og konspirasjonsteorier» (2015: 48). Allison (2014: 1257) poengterer at få stater trodde på russisk benektelse om militær deltagelse $\mathrm{i}$ Øst-Ukraina. Biersack og O'Lear (2014: 253) argumenterer for at den russiske mediedekningen av Ukraina-krisen har vært preget av «forfalskning, feilrepresentasjon og forskjønning». Byråsjefen for Voice of America i Moskva beskriver situasjonen som et «media-jernteppe», ${ }^{2}$ mens Giles (2016: 33-4) beskriver en «bred aksept for den alternative virkeligheten skapt av statlig media, og en påfølgende tilstand av kollektiv vrangforestilling, frivillig eller ikke, blant vanlige russere». Eksempler på løgn fra russisk side er historiene om «de små grønne mennene» på Krim og $\mathrm{i}$ Donbas-området, samt overdrevne fremstillinger av neo-fascisters trussel mot særlig russiske borgere.

Både Putin og Ukraina-politikken har samtidig bred folkelig støtte i Russland. Oppslutningen om Putin i Russland har siden 2014 ligget stabilt på over $80 \%$, og et klart flertall av befolkningen sier at de støtter Russlands posisjon i konflikten i Ukraina. ${ }^{3}$ Selv om propagandamaskineriet er påfallende, ville det virke noe enkelt å tilskrive den skyhøye oppslutningen til kun løgn og manipulasion av hendelsesforløp. Fra russiske myndigheters hold, samt i russisk media, er følelsen av å bli urettmessig bebreidet for sine standpunkter i Ukraina et tema som går igjen. Dette gjelder også $\mathrm{i}$ den mer desentraliserte russiske «blogosfæren» (Suslov 2014).

En legitimeringsstrategi som hittil ikke har blitt direkte adressert i analyser av russisk fremgangsmåte i Ukraina, er den omfattende rollen historie, og især historisk

\footnotetext{
${ }^{2}$ Daniel Schearf, sitert fra et intervju august 2015 i Giles (2016: 33).

${ }^{3}$ Se for eksempel siste Pew-måling publisert juni 2015, der $83 \%$ av russere sier at de støtter måten Putin håndterer forholdet med Ukraina på (Pew Research Center 2015). Levadas månedlige opinionsundersøkelser over støtte til Putin er tilgjengelig på www.levada.ru/eng/indexes-0.
} 
identitet, har spilt i offisiell russisk retorikk. ${ }^{4}$ Historiebruken er i tråd med både den $ø$ kende politiske bruken av historie under Putins regime (Miller 2012; Sherlock 2007), og den rollen historie ofte spiller i både kollektiv identitetsdannelse (Ashizawa 2008; Wilson 1995) og i utenrikspolitisk legitimeringsstrategi mer generelt (Gong 2001; May 1973; Neustadt \& May 1968). Historie har også en helt spesiell rolle i forholdet mellom Russland og Ukraina. Wilson (1995) beskrev for 20 år siden hvordan historiske myter ble brukt i politisk uenighet mellom Ukraina og Russland om Donbas-regionen, og det samme gjaldt diskusjonene rundt Krim rett etter uavhengigheten (Marples \& Duke 1995). Kappeler (2014) publiserte tidlig i 2014 en artikkel om historie som politisk våpen mellom ukrainere og russere, men da basert på tiden før den nåværende konflikten. Kappeler (2014: 112) beskrev den historiske arven som «det mest kontroversielle temaet i det russisk-ukrainske forholdet».

I denne artikkelen ønsker jeg følgelig å utforske bruken av historie i den offisielle russiske retorikken i konflikten med Ukraina. Hensikten er delvis å forsøke å forstå bedre noe av legitimeringsstrategien fra offisielt russisk hold. I så måte er artikkelen et kritisk bidrag til litteraturen om russisk informasjonskrig, hvor fokuset har vært mer på virkemidlene brukt for å fremme myndighetenes narrativ enn innholdet $\mathrm{i}$ det de formidler. Artikkelen er også et forsøk på å forstå hvordan den «historiske politikken» i Russland, grundig behandlet av andre i en innenrikspolitisk kontekst, har blitt brukt i en utenrikspolitisk konfliktsituasjon.

Mens manipulasjon av hendelser, som fremstillingen av «de små grønne mennene», er en del av en informasjonsstrategi som kan påvirke manges holdninger, spiller historiebruken på eksisterende myter og identitetsforståelser som også er vanskeligere å dementere ved såkalt «mot-propaganda» fra kritisk hold. ${ }^{5}$ Sherlock (2007) argumenterer for i sin behandling av sovjetiske og postsovjetiske historiske narrativ at narrativene både er en måte for regimets eliter å sikre seg samhold på, og en del av de normative og kognitive rammeverk som folk forstår verden gjennom. De historiske mytene som spiller på folks identitetsforståelse er også en «ekstremt effektiv» måte å drive politisk mobilisering på (Wilson 1995: 265). Malinova (2012: 368-9) påpeker i sin behandling av bruken av fortiden i russisk offisiell symbolsk politikk at myndighetene naturligvis ikke er de eneste som spiller en rolle i denne arenaen. Likevel har de en særegen stilling, blant annet gjennom de ressursene de kan

\footnotetext{
${ }^{4}$ Noen få unntak er Allison (2014), som i sin gjennomgang av mulige motiver kort nevner historiereferansene særlig i forbindelse med anneksjonen av Krim. Laruelle (2016) ser nærmere på de ulike myteprosessene orkestrert rundt «Novorossija» av russiske nasjonalistiske sirkler i forbindelse med Donbas-opprøret. Som hun imidlertid selv bemerker, eksisterer denne diskursen utenfor Putin og hans innerste sirkler - Putin selv viste til begrepet kun én gang (Laruelle 2016: 57). Suslov (2014) ser blant annet på historiske diskurser rundt Krim, men i «blogosfæren», ikke i den offisielle retorikken. Biersack og O'Lear (2014) har viet et kort avsnitt til offisiell historiebruk. Jeg vil trekke på deres analyser senere i teksten.

${ }^{5}$ Slik blant annet enkelte sentrale amerikanske tenketanker foreslår som reaksjon på russisk «informasjonskrig», se for eksempel Paul og Matthews (2016) fra Rand Corporation. NATO og EU har etablert egne kontorer som skal «identifisere og tilbakevise» desinformasjon, spesielt fra russisk hold (MacFarquhar 2016).
} 
mobilisere bak sin fortolkning og muligheten de har til å representere Russland internasjonalt.

Russisk medias tidligere nevnte sementering av regimets narrativ om Ukrainakonflikten gir de fremsatte historiske rammeverkene desto mer plass i det offentlige rom. Historiebruken har imidlertid ikke en entydig funksjon: Mens referansene til Krim passer inn i det som Wilson (1995) beskriver som betydningsfulle «historiske myter», er de historiske referansene ellers mer kontekstuelle og ikke like sterkt knyttet til russisk identitet. Imidlertid passer de inn i en trend flere har påpekt i Russland, hvor historien «bearbeides» og brukes mer aktivt som et politisk virkemiddel (Miller 2012; Kappeler 2014). De ulike formene for politisk historiebruk i Ukraina drøftes avslutningsvis.

\section{Kilder og metoder}

Gjennom en nærlesning av en rekke offisielle tekster fra president Putin og Utenriksdepartementet, vil jeg trekke frem tre historiske temaer som særlig sentrale. Temakategoriseringen er induktivt generert, det vil si «basert på observasjoner fra et utvalg [tekster]» der det sentrale for kategoriseringen er hva myndighetene selv fremhever (Sverdrup et al. 2012: 7, 28). Temaene gir ikke en uttømmende beskrivelse av russisk historiebruk i Ukraina, og det dekker heller ikke variasjon internt blant myndighetselitene. Likevel gir analysen av tekstene et viktig innblikk i hvordan konflikten i og med Ukraina har blitt legitimert fra offisielt hold. Historiebruken har betydning både for å forstå hvordan regimet klarer å mobilisere støtte rundt politikken sin, og for hvordan identitetspolitikk har blitt integrert i konflikten på russisk side.

Kildematerialet er søk etter historiske referanser i alle dokumenter som nevner Ukraina (på russisk) publisert av det russiske utenriksdepartementet mellom 1. november 2013 og 1 . april 2015, hvilket inkluderer intervjuer gitt av utenriksminister Sergej Lavrov til nasjonal og internasjonal media, hans offisielle uttalelser, pressemeldinger fra Utenriksdepartementet samt uttalelsene til de respektive russiske ambassadørene i FNs Sikkerhetsråd og OSSE. Formålet med å avgrense søket til akkurat denne tidsperioden er for å kunne dekke over et bredest mulig omfang dokumenter, samtidig som at de viktigste hendelsene i konflikten blir dekket. Dette inkluderer protestbevegelsene på Majdan, avsettelsen av president Janukovitsj, anneksjonen av Krim samt begynnelsen av opprøret i Donbas-området. I tillegg har jeg gått gjennom alle Putins uttalelser om Ukraina og Krim (i separate søk, i russisk versjon) publisert fra Presidentens kontor i samme periode, hvilket inkluderer intervjuer, uttalelser til media og større begivenheter som den årlige talen til Føderalforsamlingen og «direktelinjen» $\mathrm{i}$ april 2014. Samtlige dokumenter har vært skummet gjennom i en førstegangslesing for å finne referanser til historie. Deretter har disse blitt kodet etter hvilke temaer jeg så som gjentakende. Temainndelingen er uunngåelig nok preget av mine skjønnsmessige vurderinger. For artikkelens formål om å kartlegge de viktigste historiske temaene har jeg vurdert dette som en tilstrekkelig metode. De russiske kildene, samt de engelske referansene, er presentert i min oversettelse til norsk.

Hensikten med å inkludere både Putin og Utenriksdepartementet er å fange opp mest mulig av offisiell diskurs relatert til Ukraina-konflikten. Selv om 


\section{8 | MINDA HOLM}

Utenriksdepartementet også inkluderer uttalelser i internasjonale fora som $\mathrm{FN}$ og OSSE, er mye også rettet mot et hjemlig publikum - som offisielle uttalelser og intervjuer i russisk media. Siden Krim formelt nå er utenfor Utenriksdepartementets primære domene, står uttalelsene til Putin sentralt i diskursen om Krim. Uttalelsene om Krim inkluderer både taler i Dumaen, uttalelser til pressen og møter med offisielle representanter på Krim. Samtlige av Putins offentlige uttalelser relatert til Krim har blitt lest, men særlig presidentens tale i Kreml til Den føderale forsamlingen 18. mars 2014 står sentralt. Talen var ment å begrunne inkorporasjonen av parlamentet $\mathrm{i}$ Krim inn i den russiske føderasjonen, og er også det mest omfattende offentlige russiske dokumentet angående synet på Krim. Det er ikke en hensikt i denne artikkelen å sammenlikne historiefremstillinger blant ulike politiske organer, men snarere å trekke ut sentrale temaer i offisiell diskurs. Tilnærmingen kan følgelig sies å være et begrenset eliteperspektiv, der det offisielle Russland for praktiske formål analyseres under ett. Samtidig er det et poeng at retorikken til Utenriksdepartementet og Putin er påfallende likt hva gjelder Ukraina og historiebruk, selv om det primære publikum tidvis er forskjellig. Jeg trekker frem enkelte forskjeller underveis og i konklusjonen.

\section{Gjenforeningen: Krim}

Den russiske anneksjonen av Krim i mars 2014 ble av et flertall folkerettseksperter definert som et grovt brudd med folkeretten (se f.eks. Burke-White 2014). Vestlige myndigheter var raskt ute med å avvise gyldigheten til folkeavstemningen som ble holdt like før anneksjonen, og statusen til området står fremdeles som et av de største konfliktpunktene mellom myndighetene i Kiev, EU, USA og de russiske myndighetene. Det er lite som tyder på at Russland er villige til å gi tilbake området. Mens anneksjonen har blitt fordømt internasjonalt, har den bred støtte i Russland. I en meningsmåling utført av Levada-senteret i november 2015, sa $87 \%$ at Krim bør være en del av Russland. Dette var en oppgang fra $14 \%$ siden tilsvarende måling $i$ august 2014, og bare $3 \%$ svarte i november-målingen at Krim bør være en del av Ukraina. I samme meningsmåling svarte $57 \%$ av de som mente at Krim bør være en del av Russland på spørsmålet «hvorfor» at det er fordi Krim «alltid har vært russisk», $11 \%$ fordi Krim «i mer enn to århundrer har vært tett knyttet til Russland og dets historie», $10 \%$ fordi «Russland for 230 år siden erobret Krim», og kun $20 \%$ på grunn av folkeavstemningen i mars 2014 (Levada 2015). Legitimeringen blant russere skjer følgelig i stor grad ut fra andre premisser enn det juridiske som det internasjonale samfunnet bestrider - $\mathrm{i}$ denne meningsmålingen oppga $78 \%$ historiske grunner.

Det offisielle russiske rasjonale om Krim, særlig fremmet gjennom president Putins kontor, kan sees som todelt. For det første har det blitt fokusert på folkeavstemningen som ble holdt like i forkant av anneksionen, hvor det offisielle resultatet var at $82 \%$ av velgerskaren hadde stemt, med $96 \%$ i favør av en «gjenforening» med Russland (Morris 2014). Logikken som ble promotert i forbindelse med avstemningen vektlegger hvordan dette kan sees som et tilfelle av selvbestemmelse i overenstemmelse med eksisterende praksis i internasjonalt rett: som Putin hevdet i den velkjente «Krim-talen» 18. mars 2014, var folkeavstemningen «i full overenstemmelse med demokratiske 
prosedyrer og internasjonale rettsnormer». ${ }^{6}$ Både det prosedurale og det juridiske grunnlaget fikk bred kritikk internasjonalt. Putin har senere avvist all kritikk om at folk ble tvunget til å stemme: «man kan ikke tvinge folk ut av sine hjem og få dem til å stemme selv med våpen rettet mot seg, mens her kom $83 \%$ av befolkningen til stemmelokalene». ${ }^{7} \mathrm{Jeg}$ kommer tilbake til dette punktet senere.

For det andre: Et langt mer fremtredende tema enn folkeavstemningen er de historiske relasjonene mellom Krim og Russland. Som Putin uttalte til parlamentet like i forkant av annekteringen, «Alt på Krim taler til fordel for vår felles historie og stolthet (...) I folks hjerter og hoder har Krim alltid vært en uatskillelig del av Russland. ${ }^{8}$ Særlig fire temaer går igjen i den offisielle retorikken med tanke på religiøs og politisk historie, alle sentrale $\mathrm{i}$ «Krim-talen» 18. mars 2014:

- At Storfyrste Vladimir (Vladimir den store) ble døpt i Krim, og med det tok til seg ortodoksien som den offisielle religionen i Rus-riket. I Putins ord: «Hans spirituelle seier med tilegnelsen av ortodoksien forutbestemte det generelle grunnlaget for kulturen, sivilisasjonen og de menneskelige verdiene som forener folket av Russland, Ukraina og Hviterussland». ${ }^{9}$

- Rollen til Sevastopol i russisk militærhistorie - «en festning som står som fødestedet til Russlands Svartehavsflåte». ${ }^{10}$

- Det grunnlovsstridige ved Khrusjtsjovs beslutning i 1954 om å overføre Krim til Ukraina («må Gud dømme dem» for deres grunner), ${ }^{11}$ fremstilt av lederen av Føderasjonsrådet Valentina Matvienko i en opptreden med Putin som begynnelsen på «Krims tragiske historie» med de «mange forsøkene på å ta Krim fra Russland». ${ }^{12}$

- Det forhastede ved beslutningen i 1991 om å la Krim (for)bli en del av det nye uavhengige Ukraina, og at russiske myndigheter mislyktes med å ta opp spørsmålet om dets suverenitet: «Det var først da Krim endte opp som en del av et annet land at Russland innså at de ikke bare hadde blitt robbet, men plyndret». ${ }^{13}$

Suverenitetsspørsmålet knyttet til Krim blir her forsøkt reforhandlet retorisk. I stedet for å se på det som et suverenitetsbrudd, slik de har blitt anklaget for av en bred internasjonal opinion, fremstiller russiske myndigheter Krim som en historisk del av det suverene russiske territoriet. Grunnlaget for forbindelsen trekkes tilbake til da

\footnotetext{
${ }^{6}$ Putin, Vladimir (2014) «Poslanije Prezidenta Rossijskoj Federatsii» 18. mars. Tilgjengelig på http://kremlin.ru/acts/bank/39444. Lesedato 2. april 2015.

${ }^{7}$ Putin, Vladimir (2014) «Intervju programme «Vesti v subbotu»» 19. april. Tilgjengelig på http:// kremlin.ru/events/president/transcripts/20813. Lesedato 6. april 2015.

${ }^{8}$ Putin, Vladimir (2014) «Poslanije Prezidenta Rossijskoj Federatsii» 18. mars. Tilgjengelig på http://kremlin.ru/acts/bank/39444. Lesedato 2. april 2015.

${ }^{9}$ Putin, Vladimir (2014) «Poslanije Prezidenta Rossijskoj Federatsii»18. mars. Tilgjengelig på http://kremlin.ru/acts/bank/39444. Lesedato 2. april 2015.

${ }^{10}$ Putin, Vladimir (2014) «Poslanije Prezidenta Rossijskoj Federatsii» 18. mars. Tilgjengelig på http://kremlin.ru/acts/bank/39444. Lesedato 2. april 2015.

${ }^{11}$ Putin, Vladimir (2014) «Poslanije Prezidenta Rossijskoj Federatsii» 18. mars. Tilgjengelig på http://kremlin.ru/acts/bank/39444. Lesedato 2. april 2015.

${ }^{12}$ Putin, Vladimir (2014) «Tseremonija podpisanija zakonov o prinjatii Kryma i Sevastopolja v sostav Rossii» 21. mars. Tilgjengelig på http://kremlin.ru/events/president/news/20626. Lesedato 9. april 2015. ${ }^{13}$ Putin, Vladimir (2014) «Poslanije Prezidenta Rossijskoj Federatsii» 18. mars. Tilgjengelig på http://kremlin.ru/acts/bank/39444. Lesedato 2. april 2015.
} 
Krim først ble en del av Russland under Katarina den store i 1783, og det var overføringen av territoriet under Khrusjtsjov i 1954 som ikke fulgte de passende normative internasjonale prosedyrene de nå blir beskyldt for å bryte. Det blir særlig vektlagt at det ikke ble tatt hensyn til lokalbefolkningens ønsker.

Dette er selvfølgelig ikke en ny referanse: Ved oppløsningen av Sovjetunionen i 1991 var 1954-avtalen et mye diskutert tema i russisk politikk. Flere prominente russiske politikere, inkludert liberale politikere som tidligere St. Petersburg-ordfører Anatolij Sobtsjak, mente at 1954-loven måtte oppheves på grunn av «illegalitet» (Marples \& Duke 1995: 275-278). Samtidig, som Splidsboel Hansen (2015: 254) bemerker i en tidligere utgave av dette tidsskriftet, har vektleggingen av «å ta Krim tilbake» variert i russisk politikk. Selv om det har vært uttrykt på tvers av det politiske spekteret, har «spørsmålet om Krim ligget i dvale i det russiske samfunnet siden oppløsningen av Sovjetunionen». En gjennomgang i samme artikkel av historiebøker for russiske 11.-klassinger finner ingen referanser til 1954 og den ukrainske overtagelsen av Krim. Nå er de historiske referansene tilbake for fullt, og etter meningsmålingene å dømme (samt diskusjoner på sosiale media, se Suslov 2014) har det bred folkelig resonans.

Putins sterke vektlegging av 1954-avtalen er dermed en gjenopplivelse av et tema som tidligere har stått sentralt $\mathrm{i}$ den offentlige bevissthet. På tilsvarende måte som de nåværende myndighetene $\mathrm{i}$ Kiev tidvis har blitt demonisert, blir Sovjetunionen fremstilt som en totalitær «Andre» i relasjon til Krims befolkning. Som Putin sa i talen 18. mars med referanse til Khrusjtsjovs beslutning: «Naturligvis, i en [slik] totalitær stat ble ikke befolkningen i Krim eller Sevastopol spurt om deres mening». ${ }^{14}$ Overføringen av Krim til russisk kontroll blir dermed ikke presentert som annektering, men som en gienforening med moderlandet. Russland blir fremstilt som de «opprinnelige breddegrader» som Krim og Sevastopol returnerer til ${ }^{15}$ hvilket effektivt giør Ukraina til det fremmede territoriet som Krim har vært feilaktig knyttet til i flere tiår. Beslutningen i 1991 om å la Krim forbli en del av Ukraina blir presentert som en «historisk feiltagelse» som Russland midlertidig måtte godta for å kunne «bygge et godt naboforhold til det uavhengige Ukraina». ${ }^{16}$ På tilsvarende måte som fremstillingen av 1954, er det et sterkt fokus på at folkets mening ikke ble vektlagt. ${ }^{17}$

Sistnevnte poeng ble også gjort av Russlands FN-ambassadør Vitalij Tsjurkin i en tale i FN dagen etter Putins «Krim-tale»18. mars 2014, og i så måte er det ikke kun det hjemlige publikum de historiske referansene er ment å nå ut til.

\footnotetext{
${ }^{14}$ Putin, Vladimir (2014) «Poslanije Prezidenta Rossijskoj Federatsii» 18. mars. Tilgjengelig på http://kremlin.ru/acts/bank/39444. Lesedato 2. april 2015.

${ }^{15}$ Putin, Vladimir (2015) «Kontsert, posvjasjtsjonnyj vossojedineniju Kryma i Sevastopolja s Rossijej» 18. mars. Tilgjengelig på http://kremlin.ru/events/president/news/47878. Lesedato 5. april 2015.

${ }^{16}$ Putin, Vladimir (2014) «Poslanije Prezidenta Rossijskoj Federatsii» 18. mars. Tilgjengelig på http://kremlin.ru/acts/bank/39444. Lesedato 2. april 2015.

${ }^{17}$ Tsjurkin, Vitalij (2014) «Vystuplenije Postojannogo predstavitelja Rossii pri OON V.I.Tsjurkina na otkrytom zasedanii Soveta Bezopasnosti OON po situatsii na Ukraine, Nju-Jork» 19. mars. Tilgjengelig på www.mid.ru/BDOMP/Brp_4.nsf/arh/14130C0757AA5B2844257CA1002283A9? OpenDocument. Lesedato 4. april 2015.
} 
Utenriksdepartementet har imidlertid langt færre uttalelser knyttet til Krim enn det Putin har - hvilket ikke er særlig overraskende, i og med at Krim nå offisielt sees på som russisk territorium. De største historiske og religiøse parallellene er forbeholdt Putins taler, noe som også kan sees i sammenheng med at han oftere adresserer det hjemlige publikum. I motsvar på at anneksjonen av Krim representerer et suverenitetsbrudd og dermed også et brudd med den såkalte Budapest-avtalen av 1994 (der Russland blant annet lovet å respektere ukrainsk suverenitet), viser Utenriksdepartementet til at «Ukrainas tap av territorium var fullstendig et resultat av tunge interne prosesser, som Russland og dets forpliktelser innenfor Budapest-avtalen ikke har noe forhold til». ${ }^{18}$ Paradoksalt nok blir konflikten rundt Krim utenfor russisk UDs felt ved at det først er snakk om prosesser internt i Ukraina (bl.a. med referanse til folkeavstemningen på Krim) for at det deretter er snakk om interne russiske anliggender (og dermed igjen utenfor UDs primære domene).

\section{De hellige og kulturelle bånd}

Det er også et påfallende element av hellighet involvert i den offisielle retorikken. Som Putin uttrykte det under en konsert i markering av ettårsjubileet av anneksjonen:

Vi forstod at Krim betød mye mer for oss enn bare et stykke land, endog et strategisk stykke land (...) Saken stod her om kildene til vår historie, vår spiritualitet og vår statsdannelse, de tingene som gjør oss til et forent folk og til en forent nasjon. ${ }^{19}$

Storfyrste Vladimirs dåp i Tsjersonesus (i dag Krim) på slutten av 980-tallet blir vektlagt gjentatte ganger i offentlige uttalelser relatert til anneksjonen. Vladimirs dåp var en del av en prosess med å kristne Kievriket. I følge den klassiske tolkningen gjorde han religionen obligatorisk $\mathrm{i}$ et forsøk på å forene et territorielt og kulturelt spredt folk (se Moss 2003: 43-44). Vektleggingen av Krim som «vuggen» eller kjernen i russisk kristendom spiller også inn på en sterk tradisjon i russisk idéhistorie, hvor et sentralt element har vært skillet mellom staten - som et nødvendig onde, en byrde som en sterk leder tar på seg selv - og Guds rike, som folket er forbundet gjennom (Berdjajev 2012). Ved å fremstille Krim som en hellig del av den russiske ortodoksiens identitet, blir anneksjonen også til dels plassert utenfor sfæren av «normal», dagligdags politikk - en slags sakral versjon av sikkerhetisering. Resultatet $-\mathrm{i}$ det minste retorisk, om man aksepterer premissene - er en effektiv de-legitimering av Kievs og andres krav om at Russland må overholde suverenitetsprinsippet ovenfor Ukraina.

Mantraet om at «Krim er vårt» spiller på flere elementer, med både territoriell og religiøs betydning. Som i tilfellet med 1954-avtalen, er ikke dette en ny diskursiv ramme. En kommisjon utsendt av Jeltsin, som skulle se på Krims status, konkluderte

\footnotetext{
${ }^{18}$ MID (2014) «Zajavlenije MID Rossii v svjazi s obvinenijami v narusjenii Rossijej objazatelstv po Budapesjtskomu memorandumu ot 5 dekabrja 1994 goda» 1. april. Tilgjengelig på http://archive. mid.ru//brp_4.nsf/0/E2C2FECC50FBD22944257CAD0047429D. Lesedato 9. april 2015.

${ }^{19}$ Putin, Vladimir (2015) «Kontsert, posvjasjtsjonnyj vossojedineniju Kryma i Sevastopolja s Rossijej» 18. mars. Tilgjengelig på http://kremlin.ru/events/president/news/47878. Lesedato 5 . april 2015.
} 
med at Krim var av avgjørende «historisk, kulturell-etnisk og økonomisk betydning for Russland» (Marples \& Duke 1995: 277). På midten av 1800-tallet ble Krim brukt av russisk intelligentsia som referanse for Russlands «ekte» kulturelle røtter, og noe senere i den slavofile diskursen som en "territoriell projeksjon av et historisk alternativ» til Peter den Stores reformer og vestliggjøring (Suslov 2014: 591). Patriark Kirill har lenge før anneksjonen snakket om Krim som sentralt i det hellige Russland, og som «fundamentet for den storslåtte østlige kristne sivilisasjonen» (Suslov 2014: 593). Under Putin har også koblingene mellom staten og den ortodokse kirken blitt sterkere. Patriark Kirill vektlegger Russland som lederen av den russiske ortodokse verden, som ortodokse ukrainere regnes som en del av (Kappeler 2014: 111). I 2013 var patriark Kirill i Kiev sammen med Russlands og Ukrainas presidenter for å feire 1025-årsjubileet for kristningen av Rus’. Referansene til Putin spiller dermed på et veletablert historisk-kulturelt og religiøst rammeverk. Foruten å knytte Krim til Russland, spiller dette også opp den russiske kirken som forenende for ortodokse ukrainere og russere.

Putin forsøker også å aktivt trekke Krim inn i russisk kulturell identitet. I august 2014, fem måneder etter anneksjonen, foretok presidenten en reise til Krim der et av hovedformålene var møter med «viktige kulturpersoner». I en av talene Putin holdt under denne turen trakk han på regionens forbindelser med Tsjekhov, Pusjkin, Tolstoj, Gorkij og andre kjente russiske storheter. Putin vektla hvordan området er «uløselig knyttet til Russlands kultur og historie (...) For kreative folk, for de som kjenner og verdsetter russisk litteratur, kunst, musikk og kinematografi, er Krim en plass av spesiell betydning». ${ }^{20}$ Den forenende rollen som ortodoksien skulle spille under storfyrste Vladimir blir dermed bragt opp igjen, men nå knyttet til en bredere sosiokulturell ambisjon om et post-sovjetisk nasjonsbyggingsprosjekt:

Jeg tror at Krim selv i dag kan tjene som en unik standard; Krim kan spille en unik, samlende rolle for Russland, bli en egen form for historisk og spirituell kilde, en annen linje for forsoning for røde som for hvite [referanse til borgerkrigen], for å endelig kunne helbrede det såret som ble påført vårt folk som en del av den dramatiske splittelsen i det 20. århundre, for å gjenopprette forbindelsen mellom tid og epoker, enheten i Russlands historiske bane, vår nasjonale bevissthet, og for å gjennomføre vår egen form for kulturell og historisk terapi. ${ }^{21}$

For å oppsummere, så fremstilles perioden mellom 1954 og 2014 som et 60-årig «brudd» i Krims sanne nasjonale identitet, og Russlands anneksjon som en gjenopprettelse av det organiske, naturlige båndet. Mens retorikken resonnerer med et russisk offisielt perspektiv på Krim som går langt tilbake, markerer intensiteten og omfanget av diskursen - og det faktum at dens primære formidler er Putin selv - et

\footnotetext{
${ }^{20}$ Putin, Vladimir (2014) «Vstretsja s dejateljami kultury»14. august. Tilgjengelig på http://kremlin. ru/events/president/news/46453. Lesedato 9. april 2015.

${ }^{21}$ Putin, Vladimir (2014) «Vstretsja s tsjlenami fraktsij polititsjeskikh partij v Gosudarstvennoj Dume» 14. august. Tilgjengelig på http://kremlin.ru/events/president/news/46451. Lesedato 8. april 2015.
} 
åpenbart skifte i offisiell retorikk. Som Wilson skriver med referanse til historiske myter, må de resonnere med noe for å fungere:

De må på en eller annen måte kobles med populært minne og erfaring. Denne koblingen er lettest å oppnå og lettest for folk å forstå ved å skape «en assosiasjon med et spesifikt hjemland», et «historisk område som plasserer et felleskap i tid og rom». Dessuten vil ideologene til en gitt etnisk gruppe gjøre krav på et historisk område ved å hevde å være «stedegne» - å ha historisk vært den første gruppen, eller mest betydningsfulle gruppen, som har inntatt det landet» (1995: 266).

Det er nærliggende å anta at denne fremstillingen - hvor forsvaret av Krim også handler om forsvaret av den russiske identitet - også begrenser handlingsrommet myndighetene har til disposisjon med tanke på senere å skulle forhandle om statusen til Krim med ukrainske myndigheter. Det er heller ikke overraskende at nesten $80 \%$ av russere oppgir at Krim bør tilhøre Russland nettopp på grunn av historien (se tidligere refererte meningsmåling). Med den sterke vektleggingen av historie fra offisielt hold, medias sementering av det offisielle narrativ og det faktum at et overveldende flertall russere hovedsakelig har fătt nyhetene om Krim fra landsdekkende TV (94\%, ifølge en undersøkelse referert til i Splidsboel Hansen 2015: 251), har narrativet vært godt formidlet. Som jeg vil komme tilbake til, er historiebruken rundt Krim også i en særstilling sammenliknet med den øvrige russiske historiebruken i Ukraina.

\section{Brorskap og arv: det historiske bakteppet}

Ukraina blir gjerne sett på som den sovjetiske arvtakerstaten som er mest betydningsfull for Russland. Delvis er dette knyttet til de viktige sikkerhetspolitiske båndene mellom de to landene, særlig innenfor energi- og forsvarsindustrien. En annen dimensjon, knyttet opp mot den overnevnte arven med Krim, er relatert til et syn på Ukraina som en sentral del av det historiske grunnlaget for russisk identitet. Innbyggerne i området ble tidligere referert til som «lille-russere» (i en periode var det også områdets offisielle navn), og Kiev ble etter uavhengigheten fremdeles sett på av mange som «alle russiske byers mor». ${ }^{22}$ Både liberale og mer konservative nasjonalistiske politikere i Russland reagerte med sjokk da Ukraina erklærte sin uavhengighet i 1991, og det samme gjaldt i stor grad folk flest. Som redaktøren for den liberale avisen Moskovskije novosti uttalte da: «millioner av russere er overbevist om at uten Ukraina kan det ikke bare ikke være noe stort Russland, men det kan ikke være noen form for Russland i det hele tatt» (sitert i Kappeler 2003: 10).

Mange i Russland oppfattet da også ukrainsk uavhengighet som kun midlertidig etter Sovjetunionens oppløsning, med en avvisning av ideen om at Ukraina kunne ha en distinkt nasjonal identitet (se for eksempel Bugajski 2004). Det tette båndet har samtidig også konsistent vært en tydelig maktrelasjon: «lille-russere» ble gjerne brukt nedsettende under tsartiden, og under både tsartiden og Sovjetunionen ble ukrainsk fremstilt som et provinsielt og bakstreversk språk, i kontrast til det mer «moderne og

\footnotetext{
${ }^{22}$ Som Putin også trakk frem i Krim-talen 18. mars.
} 
avanserte» russisk (Kuzio 1996: 596). Selv om Ukraina var en selvstendig nasjon som sovjetisk republikk, ble de oppfattet som en viktig del av det russiske fellesskapet.

Fra tsartiden og fremover ble forholdet i russisk kontekst fremstilt som brorskap. Det er i videreføring av denne tradisjonen at Putin, så vel som det utenrikspolitiske etablissementet, kommer med uttalelser knyttet til brorskapet mellom de to nasjonene: «Venner, vi i Russland så alltid russere og ukrainere som ett og samme folk». ${ }^{23}$ Som to forskere fra Chatham House påpekte i 2012, «For Russland er det å opprettholde påvirkning ovenfor Ukraina mer enn bare en utenrikspolitisk prioritet; det er et eksistensielt imperativ» (Bogomolev \& Lytvynenko 2012: 1). I direktelinjen med Putin i april 2014 viste han til at «Ønsket om å sette Ukraina og Russland opp mot hverandre, å dele oss (...) har vært gjenstand for internasjonal politikk gjennom det siste århundre (. . ) Det er nok av krefter i verden som er redde for vår makt (. .) Se hva de gjorde med Jugoslavia - de delte det opp i små biter». ${ }^{24}$

Samtidig betyr ikke denne sterke identitetstilknytningen at folk mener at Russland og Ukraina territorielt skal være ett land. I en meningsmåling utført av Levada-senteret med jevne mellomrom siden 2008, har antallet russere som har ment at Russland og Ukraina burde forenes under én myndighet ligget relativt stabilt på rundt $10 \%$ (Levada 2016). ${ }^{25}$ I samme meningsmåling har det konsekvent vært et overveldende flertall på rundt $50 \%$ for at Russland og Ukraina burde være «uavhengige, men vennlige stater, med åpne grenser, uten visum og toll», etterfulgt av rundt $30 \%$ som mener grenseforholdet bør være som med alle andre stater (altså lukket) (Levada 2016). Dette er en markant endring på et knapt tiår - i 1997 var prosentandelen russere som mente landene burde forenes $64 \%{ }^{26}$

Til tross for relativt hyppige referanser til brorskap, er det historiske båndet mellom de to identitetene altså ikke det sentrale i den offentlige russiske retorikken rundt konflikten i Ukraina. Mens den historiske forbindelsen stod sentralt i de offentlige uttalelsene knyttet til Krim, er brorskapstematikken oftere et mindre diskursivt element i retorikken til både Utenriksdepartementet og Putin. Brorskapsreferansen skjer gjerne gjennom innskutte bisetninger: «Forholdet til Ukraina, med det broderlige ukrainske folk, forblir og vil alltid forbli det viktigste og mest betydningsfulle». ${ }^{27}$ Mindre ofte blir brorskapsreferansen brukt som et selvstendig retorisk poeng: «Mens Ukraina for vestlige politikere kun er et territorium for

\footnotetext{
${ }^{23}$ Putin, Vladimir (2015) «Kontsert, posvjasjtsjonnyj vossojedineniju Kryma i Sevastopolja s Rossijej» 18. mars. Tilgjengelig på http://kremlin.ru/events/president/news/47878. Lesedato 5 . april 2015

${ }^{24}$ Putin, Vladimir (2014) «Prjamaja linija s Vladimirom Putinym»17. april. Tilgjengelig på http:// kremlin.ru/events/president/news/20796. Siste lesedato 2. september 2016.

${ }^{25} \mathrm{Et}$ tydelig avvik fant sted i mars 2014, samme måned som anneksjonen av Krim, da hele $28 \%$ svarte at de burde forenes. 2 måneder senere var dette imidlertid nede igjen i $12 \%$, og har siden ikke vært høyere enn $11 \%$.

${ }^{26}$ Meningsmåling sitert i Kappeler 2003: 47.

${ }^{27}$ Putin, Vladimir (2014) «Poslanije Prezidenta Rossijskoj Federatsii» 18. mars. Tilgjengelig på http://kremlin.ru/acts/bank/39444. Lesedato 2. april 2015.
} 
geopolitiske spill, er det for oss en broderlig nasjon, som vi er knyttet til gjennom felles historie som strekker seg over flere århundre». ${ }^{28}$

Tidvis brukes det historiske båndet som en måte å forsvare Russlands respekt for Ukraina på, som et forsvar mot anklager om at Russland bruker landet som sin egen bakgård: «Det er ikke vår bakgård. Kiev er alle russiske byers mor. Det russiske språket og vår religion - den ortodokse kristendom - ble født på territoriet til det som $\mathrm{i}$ dag er Ukraina. Vi ser ikke på hverandre som utlendinger»». ${ }^{29}$ Under diskusjonene om Assosiasjonsavtalen understrekte utenriksminister Lavrov samtidig gjentatte ganger at «dette er Ukrainas suverene valg». ${ }^{30}$ Det samme trekkes frem av Putin: I den årlige talen 4. desember 2014 vektla han at Russland støttet Ukrainas ønske om suverenitet ved Sovjetunionens fall og gjennom tilhørende prosess på 1990-tallet: «Ingenting har endret seg i vår posisjon når det gjelder dette. Hvert folk har en ufravikelig suveren rett til sin egen utviklingsvei, valg av allierte, former for politisk organisering». ${ }^{31}$

\section{Brorskapets ambivalens}

Samtidig som suvereniteten trekkes frem, uttrykker Putin også misnøye med historiens utfall. Med henvisning til at det aldri falt tidligere makteliter inn å separere Ukraina og Russland «fordi man alltid har ment at de er en del av et enkelt, felles område og at det er en enkelt nasjon», følger han opp med: «Og de hadde helt rett. Men i dag så ble det nå slik at vi lever i forskjellige stater». ${ }^{32}$ Ambivalensen er åpenbar. Likevel, uttalelsene blir ikke primært brukt som en måte å direkte legitimere nåværende politikk på (hvor hovedargumentene er økonomiske og politiske), men heller som en måte å nyansere perspektivet på Russland som en «aggressor» som truer ukrainsk suverenitet: «i århundrer og århundrer har vi levd sammen i fred og vennskap $» .{ }^{33}$ Konfrontert med en kontroversiell referanse en gang giort av Putin til «Novorossija» (en russisk imperial

\footnotetext{
${ }^{28}$ MID (2014) «Kommentarij Departamenta informatsii i petsjati MID Rossii v svjazi s demontazjem pamjatnika M.I.Kutuzovu v Lvovskoj oblasti» 25. februar. Tilgjengelig på www. mid.ru/BDOMP/Brp_4.nsf/arh/04FAEDE79F0B70D644257C8A0036405E?OpenDocument. Lesedato 3. april 2015

${ }^{29}$ Lavrov, Sergej (2014) «Intervju Ministra inostrannykh del Rossii S.V.Lavrova telekanalu «Blumberg»»» 14. mai. Tilgjengelig på www.mid.ru/BDOMP/Brp_4.nsf/arh/41F16D84381234 C144257CD8006C0936?OpenDocument. Lesedato 15. april 2015.

${ }^{30}$ Lavrov, Sergej (2013) «Vstupitelnoje slovo Ministra inostrannykh del S.V.Lavrova na vstretsje s Ministrom inostrannykh del Ukrainy L.A.Kozjaroj, Kijev» 5. desember. Tilgjengelig på www. mid.ru/BDOMP/Brp_4.nsf/arh/0168CFEC889967A344257C390045F2CE?OpenDocument. Siste lesedato 26. august 2016.

${ }^{31}$ Putin, Vladimir (2014) «Poslanije Prezidenta Federalnomu Sobraniju» 4. desember. Tilgjengelig på http://kremlin.ru/events/president/news/47173. Siste lesedato 2. september 2016

${ }^{32}$ Putin, Vladimir (2014) «Prjamaja linija s Vladimirom Putinym». Tilgjengelig på http://kremlin. $\mathrm{ru} /$ events/president/news/20796. Siste lesedato 2. september 2016.

${ }^{33}$ Borodavkin, Aleksej (2014) «Vystuplenije Postojannogo predstavitelja Rossii pri otdelenii OON i drugikh mezjdunarodnykh organizatsijakh v Zjeneve A.N.Borodavkina na 25-j sessii Soveta OON po pravam tsjeloveka v khode obsjtsjej diskussii po punktu 4 povestki dnja «Situatsii v oblasti prav tsjeloveka, trebujusjtsije vnimanija so storony Soveta», Zjeneva»18. mars. Tilgjengelig på www. mid.ru/BDOMP/Brp_4.nsf/arh/0F725C977A80F6A744257CA00038A1B2?OpenDocument. Lesedato 4. april 2015.
} 
provins fra 1764 som bl.a. dekker deler av dagens Ukraina), var utenriksminister Lavrov raskt ute med å komme ham til forsvar med å understreke at det var et historisk begrep, uten noen former for «imperiale undertoner». ${ }^{34}$

Laruelle (2016) har vist at det også var eneste gang dette begrepet ble brukt av Putin og hans nærmeste politiske sirkel. Ideen om «Novorossija», ofte referert til i vestlig presse, har primært vært fremmet av nasjonalistiske sirkler som har vært misfornøyde med myndighetenes politikk i Øst-Ukraina. Wilson (1995: 268, 282) skrev for 20 år siden om den historiografiske konflikten mellom ukrainere og russere om Donbas, og viste til at Krims «sterke historiske bånd med Russland [var] vanskelig å tilbakevise», mens om Donbas var historiografien så omdiskutert at de russiske og ukrainske fremstillingene var «gjensidig motstridende på nesten hvert punkt». I så måte har den historiske tilknytningen til Krim også vært langt enklere å selge fra offisielt hold, da dets forankring i russisk identitet og historie har vært langt mindre omstridt enn tilfellet er med øvrige deler av Ukraina.

Brorskapstematikken blir først og fremst brukt for å understrekke styrken til deres forbindelse, men i kontrast til Krim blir det ikke brukt (retorisk) for å delegitimere den nåværende ukrainske territorielle suvereniteten. Som en høytstående embetsmann sa i et intervju med en russisk avis: «La oss snakke alvorlig sammen, russere og ukrainere, som to broderlige folk. Vi snakker om dette [brorskapet] hele tiden, men vi glemmer også at det ikke er lenge siden at to broderlige folk - serbere og kroater - over flere år drev og drepte hverandre»». ${ }^{35}$ Identitetsbåndet er tilstede, men i motsetning til hva som bygges opp diskursivt om Krim som konstituerende for russisk religiøs, kulturell og historisk identitet, er resten av Ukraina, også de østlige deler, en mer distinkt og atskilt enhet i retorikken. Dette er en kontrast til hva situasjonen var på 1990-tallet, hvor mange russere og russiske politikere ikke var «forberedte eller villige til å anerkjenne Ukraina som en likeverdig stat og som en separat nasjon» (Kappeler 2014: 108). Uavhengig om holdningene er tilstede, er det ikke noe Utenriksdepartementet eller Putin spiller direkte på (selv om Putins motvillige misnøye over historien kommer nær). Samtidig var brorskapsdiskursen og fokuset på vennlige relasjoner også en del av den sovjetiske diskursen, og selv om det ikke sies eksplisitt, er det helt åpenbart hvem som både da og nå er storebror i det forholdet. Det som kan virke som løse referanser, er dermed også en sementering og videreføring av en tydelig maktrelasjon etablert gjennom flere århundrer.

\section{Det som ikke nevnes}

En konstituerende del av denne maktrelasjonen er hva som ikke nevnes i diskursen om «broderlige relasjoner». I ukrainsk nasjonal identitet står massehungersnøden i

\footnotetext{
${ }^{34}$ Lavrov, Sergej (2014) «Intervju Ministra inostrannykh del Rossii S.V.Lavrova telekanalu «Blumberg»»», 14. mai. Tilgjengelig på www.mid.ru/BDOMP/Brp_4.nsf/arh/41F16D84381234 C144257CD8006C0936?OpenDocument. Lesedato 15. april 2015.

${ }^{35}$ Sjvydkoj, Mikhail (2014) «Intervju spetspredstavitelja Prezidenta Rossijskoj Federatsii po mezjdunarodnomu kulturnomu sotrudnitsjestvu, Posla po osobym porutsjenijam M.Je.Sjvydkogo radiostantsii «Kommersant FM»», 26. mai. Tilgjengelig på www.mid.ru/brp_4.nsf/newsline/EEC 3A4A1B00E541944257CA8003CA86F. Lesedato 7. april 2015.
} 
1932-33 sentralt. Mens det fremdeles er omstridt hvorvidt hungersnøden kan regnes som folkemord eller ikke (Davies \& Wheatcroft 2006; Ellman 2007), er det utenfor enhver tvil at den påførte den ukrainske befolkningen enorme lidelser. Mer enn 3 millioner ukrainere døde, og i nyere ukrainsk politikk regnes det for å være et folkemord (på ukrainsk kjent som Holodomor). Som Kappeler (2014: 114) skriver med referanse til ukrainske historikere, er det en del av nasjonal mytologi som både «forener nesten alle deler av Ukraina» og delegitimerer den sovjetiske fortiden. Folkemordet har også vært et betent tema i nyere tid, og i 2008 gikk daværende president Medvedev ut og kritiserte den daværende ukrainske president Jusjtsjenko for «nasjonaliske tolkninger av massehungersnøden i 1932/3» - i brudd med «århundrer av historiske, kulturelle og spirituelle bånd, og særlig følelsen av vennskap og gjensidig tillit». ${ }^{36}$

Russlands de facto hvitvasking av denne delen av deres «fredelige og vennlige» og «broderlige» arv står også i kontrast til deres narrativ om Krim. Her blir 1944utvisningene av særlig tatarene - et sentralt klagemål i det kollektive minnet i det området - ikke bare nevnt, men utvisningene er nå også i oppmerksomheten til russiske myndigheter. I følge offisielle kilder hadde Kommisjonen for rehabilitering av politisk undertrykkelse i oktober 2014 mottatt mer enn 14000 søknader fra ofre for etnisk basert politisk undertrykkelse. ${ }^{37}$ Putin trakk også frem Krim-tatarene under direktelinjen i april: «Det er et folk som uten tvil led alvorlig under Stalins undertrykkelser (...) Og vi må, uten tvil, giøre alt vi kan for at prosessen med innlemmelsen i den russiske føderasjon blir knyttet til rehabilitering og gjenoppretting av de juridiske rettighetene og interessene til krim-tatarene». ${ }^{38}$ Samtidig har russiske myndigheter vært lite villige til å ta imot kritikk for nåværende behandling av krimtatarer (se Coffey 2016; Blair 2016). Rehabiliteringen skjer dermed kun på bakgrunn av historisk distanse (for historiske forhold). De sovjetiske myndighetene er igjen fremstilt på trygg avstand som et totalitært «Andre».

Hva som trekkes frem i forholdet er selektivt valgt ut, slik historiske myter gjerne er. Mens tematikken rundt det historiske brorskapet ikke har stått særlig sentralt i forsvaret av russisk politikk i Ukraina, har det likevel hatt både en hjemlig legitimeringsfunksjon (det russiske publikum, ved å minne på hvor nært de står det ukrainske folk) og sannsynligvis irritert deler av det ukrainske (ved å glatte over alt det vonde $\mathrm{i}$ den felles fortiden). I så måte er det $\mathrm{i}$ tråd med det Miller (2012) beskriver som $ø$ kt politisk bruk av historie, hvor nøye utvalgte elementer av fortiden aktivt brukes for å fremme nåværende politikk. I motsetning til de historiske mytene om Krim som spiller en konstituerende rolle for folks identitet, fungerer referansene her snarere som et kontekstuelt rammeverk med veletablerte og tydelige politiske undertoner. Det historiske bakteppet til det ukrainsk-russiske forholdet blir både et forsvar for

\footnotetext{
${ }^{36}$ Medvedev sittert i Kappeler 2014: 114 .

${ }^{37}$ Kremlin (2014) «Zasedanije Komissii po reabilitatsii zjertv polititsjeskikh repressij» 23. oktober. Tilgjengelig på http://kremlin.ru/events/councils/46893. Lesedato 2. april 2015.

${ }^{38}$ Putin, Vladimir (2014) «Prjamaja linija s Vladimirom Putinym»17. april. Tilgjengelig på http:// kremlin.ru/events/president/news/20796. Siste lesedato 2. september 2016.
} 
hvorfor forholdet er særdeles viktig for Russland (vis-à-vis Nato og EU), og en påminnelse om hvor nært det forholdet har vært i både russisk og ukrainsk historie.

\section{Fedrelandskrigen, banderovtsy og nazister}

De hyppigst forekommende historiske temaene i de offentlige uttalelsene om Ukraina (sett bort fra Krim) - og foruten den «broderlige» arven - er første, og særlig andre verdenskrig. Samtlige av disse referansene blir brukt for å sette den nåværende regjeringen i Kiev til skamme for den nåværende situasjonen, så vel som aktører assosiert med regjeringen (demonstrantene, og særlig de høyreradikale bevegelsene). Av og til fremkalles 100-års jubileet til begynnelsen på første verdenskrig og 75-års jubileet for begynnelsen av den andre, hvor «målet» for kritikken er like mye vestlige regjeringer: «[disse datoene] minner oss om de katastrofale konsekvensene som følger av å tro på egen unikhet og av geopolitiske nullsumspill». ${ }^{39} 75$-års jubileet for starten på andre verdenskrig brukes også som en advarsel om «konsekvensene av å samarbeide med nazister». ${ }^{40}$

Dette er en omstridt del av ukrainsk historie. Referansene gjelder særlig rollen til nasjonalisten Stepan Bandera, lederen av Organisasjonen for Ukrainske Nasjonalister (OUN) under andre verdenskrig. Bandera var (og er fremdeles for mange) en folkehelt for sin motstandskamp mot Sovjetunionen (i 2010 erklært nasjonal helt), men flere i OUN samarbeidet med de tyske nazistene i blant annet utryddelsen av østeuropeiske jøder. Banderovtsy ble under sovjettiden brukt av russere som et skjellsord om ukrainske nasjonalister, men har også vært brukt nedsettende internt i Ukraina (Kappeler 2003: 40; Kappeler 2014: 114).

Referansene til ukrainske nasjonalisters fortid med samarbeid med nazister ser ut til å ha minst en todelt skampåføringsfunksjon. De høyreradikale bevegelsene (som Pravij Sektor) og det nasjonalistiske Svoboda-partiet trekker aktivt på Banderas arv, hvilket Russland igjen bruker for å understreke disses koblinger til (ny)nazismen. I en uttalelse fra Utenriksdepartementet påpekes det eksempelvis at regjeringspartiet Svoboda har et politisk program der man ønsker videreføring av den ukrainske stat basert på Stepan Banderas og OUNs «uavhengighetserklæring» i 1941 - en erklæring som «uttrykte et ønske sammen med Hitlers Tyskland om å kjempe for den 'nye orden' i Europa og verden». ${ }^{41}$ Dette poenget blir gjentatt flere ganger, både overfor hjemlig og internasjonalt publikum.

Tilsvarende settes de høyreradikale bevegelsene, og deres bruk av fascistiske og nazistiske symboler og referanser, i relasjon til Russlands kommende feiring av 70-års

\footnotetext{
${ }^{39}$ Lavrov, Sergej (2014) «Vystuplenije i otvety na voprosy SMI Ministra inostrannykh del Rossii S.V.Lavrova na press-konferentsii po itogam dejatelnosti rossijskoj diplomatii v 2013 godu» 21. januar. Tilgjengelig på www.mid.ru/BDOMP/Brp_4.nsf/arh/B748284D938D69B144257C6700 3AC3CB?OpenDocument. Lesedato 3. april 2015.

${ }^{40}$ Putin, Vladimir (2014) «Poslanije Prezidenta Rossijskoj Federatsii» 18. mars. Tilgjengelig på http://kremlin.ru/acts/bank/39444. Lesedato 2. april 2015.

${ }^{41}$ MID (2014) «Kommentarij MID Rossii v svjazi s situatsijej na Ukraine»18. mars. Tilgjengelig på www.mid.ru/BDOMP/Brp_4.nsf/arh/4E1C2AF0FB6AD5CA44257C9F005EF781?OpenDocument. Lesedato 4. april 2015.
} 
jubileet for frigjøringen fra «de tysk-fascistiske okkupasjonsmaktene»: «I Kiev ser det nå ut til å være andre prioriteringer». ${ }^{42}$ For det andre - og riktignok kun en gang, men til gjengjeld i den store «Krim-talen» holdt av Putin til parlamentet i forkant av anneksjonen - har den nye ukrainske regjeringen som en helhet blitt knyttet til denne fortiden. I Putins ord, med referanse til den midlertidige regjeringen i Kiev: «disse ideologiske arvingene av Bandera, Hitlers medskyldige under andre verdenskrig». ${ }^{43}$

Det har også vært flere sterke fordømmelser av ødeleggelser av monumenter fra de to verdenskrigene. De enorme ofrene som ble gjort under andre verdenskrig - i Russland «Den store fedrelandskrigen» - er en åpenbar del av russisk nasjonal identitet. Miller (2012) beskriver det endog som den eneste sentrale historiske myten på 1990-tallet. Referanser til fedrelandskrigen blir også brukt for å påføre myndighetene i Kiev skam for å ikke respektere fortiden, som i referansen ovenfor der Russlands forberedelse til 70-års-minnesmarkering settes opp mot de ukrainske myndighetenes implisitte «tillatelse» (ved å ikke gripe inn) til å la de høyreradikale partiene vanære minnesmerkene for de falne sovjetiske soldatene. Uttalelsene om både monumentene og motstanden mot de høyreradikale partiene handler generelt om å respektere de falne. Dette gjelder også for de europeiske landene og det Russland oppfatter som deres manglende oppgjør med særlig Svobodas regjeringsdeltagelse. Med utenriksminister Lavrovs ord: «Vi sa at vi ikke kan akseptere en slik holdning til minnet om dem som kjempet og vant over fascismen, til de som reddet Europa fra den brune pesten». ${ }^{44}$

Verdenskrigene står i den offisielle retorikken dermed delvis både som et minne om hva Russland har ofret (for Ukraina og Europa), og som en måte å sverte de nye myndighetene på giennom deres forbindelser til høyreradikale partier. Referansene er likevel ikke ensidig kritiske: Andre verdenskrig brukes også som påminnelse om «at våre fedre og bestefedre (...) sammen kjempet uselvisk og modig for landets frihet og uavhengighet», gjentatt av Putin både i november 2013 (før Janukovitsj sin avgang) og året etter. ${ }^{45}$ Vektleggingen av «tapperheten til det sovjetiske folk»på fronten har det siste tiåret skjedd parallelt med fremstillingen av det sovjetiske regimet som totalitært (Miller 2012: 330). Historie blir i retorikken et tydelig politisk grep, selv om referansene utenfor Krim ikke spiller på like mange identitetselementer (religiøs, kulturell, territoriell).

\footnotetext{
${ }^{42}$ MID (2014) «Kommentarij MID Rossii v svjazi s zajavlenijami ofitsialnogo predstavitelja MID Ukrainy» 26. mars. Tilgjengelig på www.mid.ru/BDOMP/Brp_4.nsf/arh/7769868CEA12D90C 44257CA7004611AC?OpenDocument. Lesedato 8. april 2015.

${ }^{43}$ Putin, Vladimir (2014) «Poslanije Prezidenta Rossijskoj Federatsii» 18. mars. Tilgjengelig på http://kremlin.ru/acts/bank/39444. Lesedato 2. april 2015.

${ }^{44}$ Lavrov, Sergej (2014) «Intervju Ministra inostrannykh del Rossii S.V.Lavrova v spetsialnom vypuske programmy «Voskresnyj vetsjer s Vladimirom Solovjevym» na telekanale «Rossija 1»» 11. april. Tilgjengelig på www.mid.ru/BDOMP/Brp_4.nsf/arh/A81D87B44C005D7E44257CB70062 BEA0?OpenDocument. Lesedato 9. april 2015.

${ }^{45}$ Putin, Vladimir (2014) «Vladimir Putin pozdravil veteranov Velikoj Otetsjestvennoj vojny, narod Ukrainy s 70-letijem osvobozjdenija Ukrainy ot fasjistskikh zakhvattsjikov» 28. oktober. Tilgjengelig på http://kremlin.ru/events/president/news/46870. Siste lesedato 2. september 2016.
} 


\section{Internasjonal historisk presedens}

Til slutt så har et gjentagende tema i russisk offentlig diskurs om den ukrainske konflikten - fra protestene først brøt ut i november 2013, til anneksjonen av Krim og den påfølgende konflikten i de østlige delene av landet - vært den internasjonale konteksten etter den kalde krigens slutt. Det gjennomgående poenget i russiske uttalelser har vært å fa frem den vestlige historiske presedensen for russiske handlinger. Tre temaer er særlig ofte nevnt både av Utenriksdepartementet og av Putin:

- NATO-intervensjonen i Kosovo i 1999 og den påfølgende uavhengighetserklæringen, samt den amerikanske invasjonen av Irak og senere opptreden i Libya. Dette bringes opp i tilknytning til Krim-spørsmålet.

- Vestlige «dobbeltstandarder» (dobbeltmoral) i måten de har opptrådd på i internasjonal politikk, og særlig monopolisering av menneskerettighetsbegrepet blant annet i relasjon til fargerevolusjonene.

- Den kalde krigens slutt og brutte løfter gitt av Vesten i etterkant, men også viktigheten av å unngå et nytt «jernteppe» i Europa med nytt antagonistisk forhold mellom Russland og vestlige land.

De to første er nokså naturlig knyttet sammen: Det samlende elementet er en motstand mot det vi kan kalle amerikansk «moralsk dominans» i internasjonal politikk, og USAs forsøk på å stigmatisere Russland for deres handlinger: «USA kan ikke ha, og har ikke, den moralske retten til å moralisere over overholdelse av internasjonal rett og respekten for andre lands suverenitet». ${ }^{46}$ Russland reagerte sterkt mot intervensjonen i Kosovo, og oppfattet NATO-tropper i tidligere Jugoslavia som det verst tenkelige scenario i det området (Levitin 2000). Tilsvarende ble uavhengighetserklæringen i Kosovo i 2007 - som Russland fremdeles ikke har akseptert oppfattet som en kulminasjon av det gapet som eksisterte mellom Russland og vestlige land hva gjaldt den «nye» internasjonale sikkerhetsordenen (Averre 2009).

Som sådan er det noe paradoksalt at Russland påkaller tidligere handlinger (intervensjonen i 1999, og den senere uavhengighetserklæringen) som den selv fordømmer, for å kunne forsvare sine egne handlinger. Som Putin uttalte i forsvar for anneksjonen: «Av en eller annen grunn er ting som kosovo-albanere fikk lov til å giøre (og vi har full respekt for dem), ikke tillatt for russere, ukrainere og krim-tatarer på Krim. Igjen, man lurer på hvorfor». ${ }^{47}$ Putin ser her ut til å balansere på en hårfin linje mellom å påkalle (historisk) presedens for å legitimere sine egne handlinger (med referanse til Kosovo), og å bruke det som kritikk for det de mener er tilsvarende illegitim vestlig atferd internasjonalt. Utenriksminister Lavrov spiller på noe av den samme logikken: «Forsøkene til de som orkestrerte løsrivelsen av Kosovo fra Serbia og

\footnotetext{
${ }^{46} \mathrm{MID}$ (2014) «Kommentarij ofitsialnogo predstavitelja MID Rossii A.K.Lukasjevitsja v svjazi s «faktologitsjeskimi vykladkami» Gosdepartamenta SSjA po situatsii na Ukraine» 6. mars. Tilgjengelig på www.mid.ru/BDOMP/Brp_4.nsf/arh/C48637A3360452D044257C9300518BDD? OpenDocument. Lesedato 4. april 2015.

${ }^{47}$ Putin, Vladimir (2014) «Poslanije Prezidenta Rossijskoj Federatsii» 18. mars. Tilgjengelig på http://kremlin.ru/acts/bank/39444. Lesedato 2. april 2015.
} 
Mayotte fra Komorene om å sette den frie viljen til befolkningen på Krim under tvil kan ikke oppfattes som noe annet enn en sterk manifestasjon av doble standarder». ${ }^{48}$

Referansene til den kalde krigen blir brukt for å argumentere mot en nullsumspilltilnærming i internasjonal politikk, med hyppige fordømmelser av logikken om at «enten er du med oss, eller mot oss». Som utenriksminister Lavrov uttalte om dette: «Det er en tenkemåte som hører til en tidligere æra, en æra som for alltid må forbli en del av historien». ${ }^{49}$ Samtidig så går denne vektleggingen av dialog noe imot forsøkene på å «stigmatisere tilbake» mot USA, hvor retorikken er mer antagonistisk. Talen er ærlig aggressiv når det kommer til å kritisere USA for demokratipromotering og det Russland oppfatter som dertil knyttet innblanding $\mathrm{i}$ andre lands suverenitet. Som viseutenriksminister Gatilov uttalte $i$ et intervju med ITAR-TASS med referanse til fargerevolusjoner og vestlig vektlegging av å respektere retten til fredelige protester: «Verken én enkel myndighet eller en gruppe myndigheter har rett til å monopolisere tolkningen av menneskerettighetsnormer (...) Enda verre er det når menneskerettigheter blir et instrument for å fremme geopolitiske interesser». ${ }^{50}$ Hovedpoenget er her å kritisere hvordan menneskerettigheter har blitt brukt politisk for å legitimere det Russland definerer som innblanding $i$ «interne anliggender», i dette tilfellet regimeendringer.

Den samme logikken - kritikken av innblanding i interne anliggender under påskudd av andre hensikter - går igjen i fremstillingen av bombingen av Libya i 2011. Russisk UD påpeker her - i motsvar på NATOs kritikk av russisk oppførsel i Ukraina - at koalisjonstyrkene valgte å «kreativt tolke FNs sikkerhetsrådsresolusjon 1973, og under påskudd av å beskytte befolkningen ga de støtte til én side av den interne konflikten i Libya og giennomførte massive bombinger også av regjeringsstyrker». ${ }^{51} \mathrm{I}$ og med at Russland implisitt ga støtte til resolusjon 1973 ved å ikke legge ned veto (men med forbehold om at regimeendring ikke var en del av målet), er poenget at NATO har misbrukt godviljen gitt av Russland i oppfyllelsen av egen politisk agenda (avsettelsen av Gaddafi). Brutte løfter står generelt sentralt i retorikken rundt vestens rolle i Ukraina og det tidligere Sovjet. I utenriksminister Lavrovs ord med referanse til utvidelsen av NATO:

Vi ble lovet at man ikke skulle flytte NATOs militære infrastruktur mot våre grenser - vi ble lurt. Vi ble lovet at det ikke skulle være noen militære fasiliteter tilknyttet NATO på territoriet til nye medlemmer. Disse løftene ble av oss på en konstruktiv måte tatt imot

\footnotetext{
${ }^{48}$ Lavrov, Sergej (2014) «Statja Ministra inostrannykh del Rossii S.V.Lavrova «Vykhod iz ukrainskogo krizisa», opublikovannaja v gazete «The Guardian»» 7. april. Tilgjengelig på www. mid.ru/BDOMP/Brp_4.nsf/arh/5D21C9FB97C66D9744257CB4001AF6A8?OpenDocument. Lesedato 8. april 2015

${ }^{49}$ Lavrov, Sergej (2014) «Vstupitelnoje slovo Ministra inostrannykh del Rossii S.V.Lavrova na vstretsje s Ministrom inostrannykh del Ukrainy L.A.Kozjaroj, Mjunkhen» 1. februar. Tilgjengelig på www.mid.ru/BDOMP/Brp_4.nsf/arh/0997C7726DEEF4A444257C72004654AD?OpenDocument. Lesedato 3. april 2015.

${ }^{50} \mathrm{MID}$ (2014) «Intervju zamestitelja Ministra inostrannykh del Rossijskoj Federatsii G.M.Gatilova agentstvu ITAR-TASS» 11. april. Tilgjengelig på www.mid.ru/BDOMP/Brp_4.nsf/arh/E52728628 F5BA32344257CB70063621B?OpenDocument. Lesedato 8. april 2015.

${ }^{51}$ MID (2014) «Kommentarij Departamenta informatsii i petsjati MID Rossii v svjazi s podgotovlennym v NATO «obzorom» sotrudnitsjestva s Rossijej» 17. april. Tilgjengelig på http://archive.mid. ru//brp_4.nsf/newsline/DD04C4C0105752AE44257CBD0030A1DB. Lesedato 6. april 2015.
} 
muntlig. (...) Men når det gjaldt våre spørsmål, og hvorfor man ikke kunne giøre løftene juridisk bindende fikk vi til svar: «Det er ikke mulig, rent politisk, og generelt må dere ikke bekymre dere; alt det vi gjør, det er ikke mot dere». ${ }^{52}$

Retorikken om internasjonal politikks moderne historie er dermed preget av dobbelthet. På den ene siden vektlegges det hvordan Russland har forsøkt å bidra til en ny form for ikke-antagonistisk verdensorden. Mens fokuset er på samarbeid, gis det også små «stikk» mot at det samarbeidet ikke alltid har blitt fulgt opp fra den andre enden. Dette gjelder særlig NATOs utvidelse østover, som sitatet fra Lavrov ovenfor illustrerer. Referansene til den internasjonale presedensen på intervensjoner er mer ambivalente. På den ene siden - relatert opp mot Krim - brukes det som en måte å forsvare russiske handlinger på, ved å vise til at disse er i tråd med eksisterende sedvane. Samtidig brukes de tidligere intervensjonene som negative eksempler på vestlig, og særlig amerikansk, makt(mis)bruk. Poenget russiske myndigheter forsøker å få frem er tydelig: Russland har forsøkt å bidra til å skape en ny verdensorden basert på samarbeid, og har oppført seg deretter. Vesten, og særlige NATO og USA, har derimot gientatte ganger handlet i egeninteresse og dermed brutt de avtalene man hadde. I reaksjon på at NATO i 2014 annonserte at de skulle «vurdere» partnerskapsavtalen med Russland, kom Utenriksdepartementet med en uttalelse der denne tankegangen ble oppsummert:

Til tross for kontroversene (NATOs utvidelse, byggingen av rakettforsvar og den manglende overholdelsen av alliansen omkring folkeretten), har Russland i alle disse årene ærlig forsøkt å utvikle samarbeidet med NATO innenfor områder av felles interesser (kampen mot terrorisme, narkotikahandel, piratvirksomhet, respons på naturlige og menneskeskapte katastrofer, samarbeid om Afghanistan), og gjort en innsats for å løse arven fra den kalde krigen. Hva angår det som NATO har drevet med, taler fakta mye bedre enn ord. ${ }^{53}$

Kritikken som kommer fra vestlig hold i forbindelse med russisk oppførsel i Ukraina blir dermed både møtt med forsvar basert på eksisterende internasjonale normer og internasjonal (historisk) presedens, og gjennom angrep på det de mener er problematisk vestlig oppførsel over de siste 25 årene. Likevel er det et viktig poeng at mesteparten av retorikken er innenfor rammen av internasjonal rett. Mens Russland blir kritisert for å bryte den, forsøker myndighetene å argumentere for at det er rettmessig handling innenfor deres tolkning. Først og fremst gjelder denne argumentasjonen Krim og retten til selvbestemmelse, ettersom russiske myndigheter fremdeles benekter militær deltagelse i øvrige deler av Øst-Ukraina. Som Borgen (2009) har poengtert tidligere med referanse til Kosovo og Sør-Ossetia, er det nokså

\footnotetext{
${ }^{52}$ Lavrov, Sergej (2014) «Intervju Ministra inostrannykh del Rossii S.V.Lavrova programme «Vesti v subbotu s Sergejem Brilevym»»" 29. mars. Tilgjengelig på http://archive.mid.ru//brp_4.nsf/0/ A6EAE2AA906599B744257CAA002C0660. Lesedato 5. april 2015.

${ }^{53}$ MID (2014) «Kommentarij Departamenta informatsii i petsjati MID Rossii v svjazi s podgotovlennym v NATO «obzorom» sotrudnitsjestva s Rossijej»17. april. Tilgjengelig på http://archive.mid.ru//brp_4.nsf/newsline/DD04C4C0105752AE44257CBD0030A1DB. Lesedato 6 . april 2015 .
} 
naturlig at Russland innretter seg etter folkerettens språk, og, på lik linje som andre stormakter, forsøker å påvirke det juridiske fortolkningsrommet i såkalte «gråsoner».

Likevel har de tatt et skritt videre med Krim, ettersom handlingene og tolkningen er langt forbi juridiske gråsoner. Siden folkeretten er det primære språket som stater opererer med i spørsmål om både krig og krav om selvbestemmelse, er det ikke overraskende at Russland fortsetter med den praksisen (selv når tolkningen avvises kontant av et flertall stater og folkerettseksperter). Når det gjelder den mer krasse kritikken på vestlig oppførsel etter den kalde krigens slutt, er det som regel i relasjon til den øvrige konflikten i Ukraina. Skytset er her særlig rettet mot moraliserende argumentasjon fra vestlig hold, som russiske myndigheter søker å kontre ved å vise til gap mellom vestlige handlinger og retorikk gjennom 1990- og 2000-tallet.

I motsetning til de historiske mytene som myndighetene spiller på i Krim og med referanse til brorskap og arv, er historiereferansene til internasjonal politikk «grunnere» med tanke på identitet. Likevel spiller referansene åpenbart en viktig rolle i legitimeringen av posisjonen i Ukraina, i dette tilfellet rettet både direkte mot et internasjonalt publikum (som i FN, i intervjuer med vestlig presse osv.) og et nasjonalt (gjennom Lavrovs intervjuer i nasjonal media, og Putins tilsvarende vektlegging i arenaer som den årlige talen til Den føderale forsamlingen og «direktelinjen»). Retorikken representerer dermed en annen form for politisert bruk av historie knyttet til det internasjonale rom.

\section{Oppsummering og konklusjoner}

Historiens sentrale rolle i den offisielle russiske retorikken om Ukraina kan sees i sammenheng med den økte bruken av historie i russisk politikk og offentlighet. ${ }^{54}$ Bruken er imidlertid mangefasettert, og fortiden har blitt brukt nokså annerledes rundt Krim sammenliknet med resten av Ukraina. Når det gjelder Krim har det primære formålet vært å svekke betydningen av den historien som forbinder Krim med Ukraina. Dette har blitt gjort både gjennom å skape et sterkt narrativ om «helligheten» av regionen for russisk politisk, kulturell og religiøs identitet, og gjennom de-legitimering av tidligere sovjetiske makthavere - både i 1954, da Krim ble gitt til Ukraina, og i 1991 i forbindelse med uavhengigheten. Den parallelle diskursen om angivelige problemer på Krim etter avsettelsen av president Janukovitsj spiller inn på forestillingen om at Russland i denne sammenheng er en «frelser». Med tanke på hvor sterkt nasjonalistisk narrativet om Krim har blitt, er det vanskelig å se for seg at den russiske posisjonen her kan snus i nær fremtid (slik både ukrainske myndigheter og andre involverte aktører krever). De historiske referansene har lenge versert $i$ russisk offentlig diskurs, men, som andre har vist, har de ligget relativt stille de siste tjue årene (Splidsboel Hansen 2015). Siden anneksjonen er de tilbake for fullt, og etter både meningsmålinger og diskusjoner i sosiale media å dømme har de bred resonans i befolkningen.

\footnotetext{
${ }^{54}$ Se foruten tidligere referanser også Enstad 2011 og Gjerde 2013 i samme tidsskrift.
} 


\section{4 | MINDA HOLM}

Narrativene knyttet til den øvrige konflikten i Ukraina er i kontrast primært sentrert på nåværende økonomiske og politiske krav og bekymringer (se også Sakwa 2016). Den felles historien er imidlertid et sentralt bakteppe. De to sentrale historiske temaene er «brorskapet» mellom nasjonene - med referanse til deres felles (østslaviske) fortid - og til de to verdenskrigene. Hva gjelder det første temaet ser intensjonen ut til å være å understreke det spesielle båndet mellom statene, samtidig som russiske myndigheter vektlegger (retorisk) at de anerkjenner suvereniteten til dagens Ukraina. Implisitt i brorskapsreferansene er en tydelig maktrelasjon, der Ukraina er «lillebror». Referansene til det andre temaet, verdenskrigene, blir som regel brukt både av Utenriksdepartementet og Putin for å påføre skam: både for å ikke ta de nødvendige historiske lærdommene fra første og andre verdenskrig, og for å samarbeide med høyreradikale aktører som Pravij Sektor og Svoboda (med referanse til enkelte ukrainske nasjonalisters samarbeid med de tyske nazistene).

I motsetning til Krim-spørsmålet, hvor det eksisterer en offentlig diskurs knyttet til de politiske undertrykkelsene på særlig 1940-tallet, er det lite nyansert eller selv-reflektert perspektiv på den lidelsen som det sovjetiske regimet påførte Ukraina. Historie blir dermed et politisk verktøy både i hva som blir vektlagt og hva som blir utelatt i retorikken. Dette er i tråd med både de tendensene man har sett i offisiell politisert bruk av historie under Putin generelt, og med den «krigen om minnene» som lenge har eksistert mellom Ukraina og Russland. ${ }^{55}$ De historiske mytene om Krim spiller på flere lag i russisk identitet (den ortodokse tro, territoriell betydning og kulturell arv), men det århundrelange «brorskapet» og andre verdenskrig er også en tydelig del av russisk offisiell retorikk.

Et gjentagende tema som jeg har forsøkt å adressere er knyttet til verdensordenen etter den kalde krigens slutt. Den primære intensjonen er her å bruke historien fra vestlige (og særlig amerikanske) handlinger som presedens (dere gjorde det først), og påføring av skam (dere har ingen rett til å anklage eller moralisere mot oss). Denne formen for motstigmatisering underbygger både narrativet rundt Krim og rundt konflikten generelt. Det virker nærliggende å se dette i sammenheng med den utviklingen vi har sett i Russland i en lengre periode nå, der det er tydelig økt misnøye med den såkalte vestlig-definerte liberale verdensordenen. Internasjonal politikks moderne historie - fra den kalde krigens slutt og fremover - står her som det sentrale bakteppet i retorikken.

Formålet med denne artikkelen har vært å se på hvordan russiske myndigheter har brukt historie for å begrunne sine synspunkt og handlinger rundt konflikten $\mathrm{i}$ Ukraina. Det empiriske materialet har vært begrenset i tid og omfang, og burde utvides ytterligere for å kunne trekke mer presise og nyanserte konklusjoner. Eksempelvis kan det tenkes at det er nyanseforskjeller mellom Utenriksdepartementet og Putin som ikke har kommet frem her (hvor det viktigste poenget har vært at Putin snakker mer og mer nasjonalistisk om Krim). Delvis handler dette om hvem publikum er, men det er mulig at det også er andre forskjeller å spore. Samtidig vil det være for lettvint å hevde at UDs primære publikum er det internasjonale. Når utenriksminister Lavrov intervjues på russisk TV eller UD uttaler seg på nasjonale pressekonferanser, er budskapet heller primært rettet mot russere. Det har også vært

\footnotetext{
${ }^{55}$ Begrepet er hentet fra Kappeler 2014 .
} 
påfallende at de historiske mytene som trekkes frem - om brorskapet, og om andre verdenskrig - er en del av retorikken til både UD og Putin.

Det er vanskelig å si med sikkerhet hvor mye bruken av historie generelt har å si for hvor legitimt retorikken og handlingene til russiske myndigheter oppfattes i Russland. Det er likevel påfallende at de historiske mytene står så sentralt $\mathrm{i}$ folks begrunnelse for at Krim bør være russisk. Uten at det skal leses som et forsvar for russiske handlinger, er det av betydning for å kunne forstå hvordan den politikken som blir fordømt av så mange internasjonalt har kunnet blitt begrunnet og forsvart overfor særlig det hjemlige publikum. Samtidig er det et viktig poeng at legitimeringen skjer parallelt med de strategiene som har blitt påpekt i litteraturen om informasjonskrig, hvilket gir myndighetene stor kontroll over narrativene i offentligheten. Som andre har påpekt, er det i Russland svært lite motstand mot myndighetenes fremstilling av konflikten med Ukraina (Pomorantsev 2015: 41; Splidsboel Hansen 2015: 264). Poenget her har vært å trekke frem noe av det innholdet som formidles i de godt kontrollerte narrativene om konflikten. Selv om verktøyene i den russiske informasjonskrigen er viktig å trekke frem, har den retoriske legitimeringsstrategien - i dette tilfellet gjennom bruken av historie - også en åpenbar betydning for å forstå støtten og handlingsrommet for russisk politikk i Ukraina.

\section{Om artikkelen}

Tusen takk til redaktørene og de anonyme fagfellene for veldig gode og konstruktive innspill. Særlig takk til redaktør Kristian Gjerde for å ha gjort transkriberingsprosessen mye enklere med NØFs nye transkriberingsverktøy.

\section{Litteratur}

Alle dokumenter som nevner «Ukraina» publisert av det russiske Utenriksdepartementet, publisert i perioden mellom 1. november 2013 og 1. april 2015 på russisk ble skummet gjennom etter referanser til historie, totalt ca. 1700 dokumenter. Dokumentsøket ble gjort gjennom departementets egne søkesider, tilgjengelig på www.mid.ru.

Alle president Putins offentlige uttalelser relatert til Krim samt uttalelser om Ukraina i perioden 1. november 2013 til 1. april 2015 på russisk, i separate søk, totalt ca. på 420 Ukraina generelt og ca. 190 på Krim (her er det overlapp). Samtlige dokumenter ble skummet gjennom etter referanser til historie. Dokumentsøket ble gjort gjennom presidentkontorets egne søkesider, tilgjengelig på www.kremlin.ru.

Allison, Roy (2014) «Russian 'Deniable' Intervention in Ukraine: How and Why Russia Broke the Rules». International Affairs 90 (6): 1255-1297.

Ashizawa, Kuniko (2008) «When Identity Matters: State Identity, Regional Institution Building, and Japanese Foreign Policy». International Studies Review 10 (3): 571-598.

Averre, Derek (2009) «From Pristina to Tskhinvali: The Legacy of Operation Allied Force in Russia's Relations with the West». International Affairs 85 (3): 575-591.

Berdjajev, Nikolai (2012) Den russiske idé. Oversatt fra russisk av Torgeir Boehler. Oslo: Solum Forlag.

Biersack, John \& Shannon O’Lear (2014) «The Geopolitics of Russia's Annexation of Crimea: Narratives, Identity, Silences, and Energy». Eurasian Geography and Economics 55 (3): 247-269.

Borgen, Christopher J. (2009) «The Language of Law and the Practice of Politics: Great Powers and the Rhetoric of Self-Determination in the Cases of Kosovo and South Ossetia». Chicago fournal of International Law 10 (1): 1-33.

Bugajski, Janusz (2004) Cold Peace: Russia's New Imperialism. Westport, CT: Praeger.

Darczewska, Jolanta (2014) «The Information War on Ukraine New Challenges». The Cicero Foundation, Cicero Foundation Great Debate Paper 14/08. 


\section{MINDA HOLM}

Davies, Robert W. \& Stephen G. Wheatcroft (2006) «Stalin and the Soviet Famine of 1932-33: A Reply to Ellman». Europe-Asia Studies 58 (4): 625-33.

Dougherty, Jill (2015) «How the Media Became One of Putin's Most Powerful Weapons». The Atlantic 21. april. Tilgjengelig på www.theatlantic.com/features/archive/2015/04/how-the-media-became-putins-mostpowerfulweapon/391062/. Lesedato 14. august 2016.

Ellman, Michael (2007) «Stalin and the Soviet Famine of 1932-33 Revisited». Europe-Asia Studies 59 (4): $663-93$.

Enstad, Johannes Due (2011) «Putinistisk historiepolitikk: Oppussing av fortiden i Putins Russland». Nordisk Østforum 25 (4): 321-44.

Giles, Ken (2016) Russia's New Tools for Confronting the West: Continuity and Innovation in Moscow's Exercise of Power. London: Chatham House.

Gjerde, Kristian Lundby (2013) «Bruken av historie i Putins Russland: Kremls søken etter konsensus 20002010». Nordisk Østforum 27 (1): 31-46.

Gong, Gerrit W. (2001) «The Beginning of History: Remembering and Forgetting as Strategic Issues». Washington Quarterly 24 (2): 45-57.

Götz, Elias (2015) «It’s Geopolitics, Stupid: Explaining Russia’s Ukraine Policy». Global Affairs 1 (1): 3-10.

Kappeler, Andreas (2003) "'Great Russians' and 'Little Russians'»: Russian-Ukrainian Relations and Perceptions in Historical Perspective». The Donald W. Treadgold Papers in Russian, East European, and Central Asian Studies No. 39.

Kappeler, Andreas (2014) «Ukraine and Russia: Legacies of the Imperial Past and Competing Memories». fournal of Eurasian Studies 5 (2): 107-115.

Kuzio, Taras (1996) «National Identity in Independent Ukraine: An Identity in Transition». Nationalism and Ethnic Politics 2 (4): 582-608.

Laruelle, Marlene (2016) «The Three Colors of Novorossiya, or the Russian Nationalist Mythmaking of the Ukrainian Crisis». Post-Soviet Affairs 32 (1): 55-74.

Levada (2015) «'Krymnasj’ — zvutsjit gordo» 23. november. Tilgjengelig på www.levada.ru/2015/11/23/ krymnash-zvuchit-gordo/. Lesedato 18. august 2016.

Levada (2016) «Rossijsko-ukrainskije otnosjenija v zerkale obsjtsjestvennogo mnenija: monitoring janvarjafevralja 2016»10. mars. Tilgjengelig på www.levada.ru/2016/03/10/rossijsko-ukrainskie-otnosheniya-vzerkale-obshhestvennogo-mneniya-2/. Lesedato 26. august 2016.

MacFarquhar, Neil (2016) «A Powerful Russian Weapon: The Spread of False Stories». The New York Times 28. august. Tilgjengelig på www.nytimes.com/2016/08/29/world/europe/russia-sweden-disinformation. html?smprod=nytcore-ipad\&smid=nytcore-ipad-share\&_r=2. Lesedato 28. august 2016.

Malinova, Olga (2012) «Ispolzovanije prosjlogo v rossijskoj ofitsialnoj simvolitsjeskoj poitike» i Aleksei Miller \& Maria Lipman (red.) Istoritsjeskaja politika v XXI veke. Moskva: Novoje literaturnoje obozrenije (368-398).

May, Ernest (1973) Lessons from the past: the use and misuse of history in American foreign policy. Oxford: Oxford University Press.

Miller, Aleksej (2012) «Istoritsjeskaja politika v Rossii: novyj povorot?» i Aleksei Miller \& Maria Lipman (red.) Istoritsjeskaja politika $v$ XXI veke. Moskva: Novoje literaturnoje obozrenije (328-367).

Morris, Chris (2014) «Crimea Referendum: Voters back Russia Union». BBC 16. mars. Tilgjengelig på www. bbc.com/news/world-europe-26606097. Lesedato 2. mai 2015.

Moss, Walter G. (2003) A History of Russia: Volume 1, to 1917. London: Anthem Press.

Paul, Christopher \& Miriam Matthews (2016) «The Russian 'Firehose of Falsehood' Propaganda Model: Why It Might Work and Options to Counter It». Santa Monica, CA: RAND Corporation. Tilgjengelig på www. rand.org/pubs/perspectives/PE198.html. Lesedato 18. august 2016.

Pew Research Center (2015) «Russians Overwhelmingly Support Putin's Foreign and Domestic Policies». 8. juni. Tilgjengelig på www.pewglobal.org/2015/06/10/nato-publics-blame-russia-for-ukrainian-crisisbut-reluctant-to-provide-military-aid/russia-ukraine-report-21/. Lesedato 19. august 2016.

Pomerantsev, Peter (2015) «The Kremlin's Information War». Fournal of Democracy 26 (4): 40-50.

Popescu, Nicu (2015) «Hybrid Tactics: Neither New nor Only Russian». EUISS Issue Alert 4. Tilgjengelig på www.iss.europa.eu/uploads/media/Alert_4_hybrid_warfare.pdf. Lesedato 17. august 2016.

Sakwa, Richard (2016) Frontline Ukraine: Crisis in the Borderlands. London, New York: IB Tauris.

Sherlock, Thomas (2007) Historical Narratives in the Soviet Union and Post-Soviet Russia: Destroying the Settled Past, Creating an Uncertain Future. New York: Palgrave Macmillan.

Splidsboel Hansen, Flemming (2015) «Italesættelsen af en annektering: Rusland og Krim». Nordisk Østforum 29 (3): $249-269$.

Sverdrup, Ulf, Joakim Hertzberg Ulstein, Mikkel Frøsig Pedersen, Halvard Leira \& Ståle Ulriksen (2012) «Norske interesser - sett fra utestasjonene». Oslo: Norsk Utenrikspolitisk Institutt (NUPI). Tilgjengelig på 
www.regjeringen.no/globalassets/upload/ud/vedlegg/refleksii/norske_interesser_fra_utestasjonene_nupi_rapp. pdf. Lesedato 28. mars 2015.

Suslov, Mikhail D. (2014) «'Crimea Is Ours!' Russian Popular Geopolitics in the New Media Age». Eurasian Geography and Economics 55 (6): 588-609.

Tsygankov, Andrei (2015) «Vladimir Putin's Last Stand: The Sources of Russia's Ukraine Policy». Post-Soviet Affairs 31 (4): 279-303.

UN News Centre (2016a) «Ukraine: UN Reports Uptick in Internal Displacement as Country's Conflict Grinds on». 9. juni. Tilgjengelig på www.un.org/apps/news/story.asp?NewsID =51099\#. WAshODtxu71. Lesedato 2. september 2016.

UN News Centre (2016b) «UN Warns of Escalating Tension in Eastern Ukraine as Casualties Hit Highest Since Last August». 3. august. Tilgjengelig på www.un.org/apps/news/story.asp?NewsID=54615\#. WAsgijtxu71. Lesedato 2. september 2016.

Wilson, Andrew (1995) «The Donbas between Ukraine and Russia: The Use of History in Political Disputes». fournal of Contemporary History 30 (2): 265-289. 